\title{
Research on the Performance Evaluation System of Listed Companies in Financial Securities Industry
}

\author{
Cui Zhe*, Zhou Jiahui, Wang Guohua \\ School of Business, Nantong University, Nantong, China
}

Email address:

7790@vip.163.com (Cui Zhe)

${ }^{*}$ Corresponding author

\section{To cite this article:}

Cui Zhe, Zhou Jiahui, Wang Guohua. Research on the Performance Evaluation System of Listed Companies in Financial Securities Industry. Science Journal of Business and Management. Vol. 5, No. 3, 2017, pp. 122-131. doi: 10.11648/j.sjbm.20170503.16

Received: April 7, 2017; Accepted: April 24, 2017; Published: June 14, 2017

\begin{abstract}
With the rapid development of Chinese domestic economy, the listed companies affected by various internal and external factors is gradually deepened, so as to continuously improve the management level, more attention is paid to risk management gradually. To improve the operating performance of listed companies in China is not only the objective needs of their own development, but also the practical needs to deal with international challenges and competition. Firstly, the theory was introduced, and then constructing China's securities within the listed company's operating performance evaluation system through relevant empirical research, that single indicators to evaluate the performance of listed securities companies often have limitations, because in the financial system is the perfect indicator not exist, there are no indicators of the single and objects, can not be fully present financial position. As listed securities company performance is affected by many factors, it is necessary to establish a comprehensive evaluation model to the performance of listed securities companies to make a comprehensive and objective evaluation. Evaluation model established in this paper is a discussion to the performance of listed securities company comprehensive evaluation.
\end{abstract}

Keywords: Listed Company, Performance Evaluation, Evaluation System

\section{Introduction}

\subsection{Background and Significance}

\subsubsection{Research Background}

To get rid of the simple assessment under the previously planned economic system, China publishes a series of inspection methods in enterprise operating performance after putting socialist market economy system into practice. But till now, these systems are still in lack of core indicators. The correlations between indicators are uneven. Some use financial data repeatedly, some don't reflect data fully, some even contradict with each other. All of these block the further promotion of the evaluation system. With the rapid development of Chinese domestic economy, the listed companies affected by various internal and external factors is gradually deepened, so as to continuously improve the management level, more attention is paid to risk management gradually. To improve the operating performance of listed companies in China is not only the objective needs of their own development, but also the practical needs to deal with international challenges and competition.

\subsubsection{Research Significance}

The significance of the research are as follows.

Firstly, the market internationalization and international competition are in need of the scientific and reasonable listed company's operating performance evaluation system. China are facing with increased challenges and threats from international market after entry into WTO. Thus, it's a trend to construct China's securities within the listed company's operating performance evaluation system.

Secondly, China's securities are ought to choose one which suits themselves best from plenty of evaluation models in order to get closer to the enterprises' real situation. Meanwhile, enterprise's stakeholders can obtain truer and more reliable information. In addition, enterprises can also improve in accordance with the evaluation results.

At last, scientific listed company's operating performance evaluation system helps allocate resources rationally and 
helps enhance operating performance and core competitiveness in a stable and rapid way. The rate and capability of development are improved for this reason.

\subsection{Research Status}

\subsubsection{Summary on Foreign Research}

Since 1970 s to 1990 s, western academia started to pay more attention to operating performance evaluation of the financial securities industry. The phenomenon was mostly caused by the appearance of plenty of problem banks. Under that circumstance, many operating performance evaluation models about financial securities enterprises rose in response to the proper time and conditions. All of these models were from shallow to deep and from simple to complex.

Since 1990s, people started to deeply analyze banks' operating performance. The practical activity in banks' operating performance analysis together organized by banks, supervision department and fitch ratings became abundant. At that time, the evaluation was process that establish indicator system first and then form evaluation model. To be specific, evaluation models include multivariate discriminant analysis and expert system and so on. Although evaluation models emerge one after another and apply to practice, the universally acknowledged and unified method isn't formed at present.

\subsubsection{Summary on Domestic Research}

Scholars like Zhang Zhongchao, Hua Junfeng, Gan Maozhi and so on assume that unreasonable operating performance system at present leads to so many drawbacks of China's listed securities company. They put forward an idea that evaluation system are supposed to be reestablished from the three views of macroscopic, the meso, microcosmic. Firstly, listed securities company's stragetic objectives should be served as macro assessment target. Secondly, Economic Value Added evaluation indicator should be served as meso auxiliary subsystem. Thirdly, non-financial indicators should be served as microcosmic testing goal and balanced scorecard can be used.

In 2015, Li Hongwei and Ye Qing raised doubts about the traditional method which puts profit maximization as operation target. They evaluated EVA rate of return and calculated EVA value on the basis of Economic Value Added evaluation indicator in accordance with 2013 operating performance of five financial enterprises. They analyzed and compared the results and traditional financial indicators, and proved that the reasonability of Economic Value Added evaluation indicator in financial enterprise operating performance evaluation.

\section{Theoretical Background}

\subsection{Summary on Listed Company Operating Performance Evaluation}

Performance evaluation is based on performance objectives and adopts the method combining qualitative and quantitative analysis and calculation in the situation of input, output and benefit in social organization. From general point of view, performance evaluation includes not only that of social organization, but also that of internal organization and personnel inside. So, performance evaluation can be regarded as an activity which obtains the analysis and judgement according to efficiency, service quality and social satisfactory when management personnel fulfill their social responsibility and specifically assesses and divides the input, output and outcomes in public sector management. Performance evaluation can reach an agreement in production efficiency and quality between organization and person. Thus, it has incentive and restraint effect in managing organization. According to the definition, the characteristics of performance evaluation are as follows.

Firstly, considering the content, performance evaluation belongs to the scope of comprehensive management. Since it's hard for public sector to estimate performance quantitatively and public sector performance technology has certain limits. In practical work, people mainly measure performance evaluation around benefit, efficiency and economy. As China's government advances public effectiveness building constantly, the public pay full attention to public officers' responsibility fulfilling condition and they also make a social assessment of quality of service.

Therefore, scholars start to regard the assessment of government public management quality and public satisfaction index as the important part of public performance evaluation.

Secondly, considering the factors, performance evaluation constitutes an integrated system. performance evaluation system contains choosing target of evaluation, confirming evaluation procedure, choosing assessment criteria, collecting material and the process of forming conclusion. Integrated performance evaluation cannot lack any one of these factors and process. So, performance evaluation constitutes an integrated system.

Thirdly, considering the procedure, performance evaluation is a dynamic process. Performance evaluation is not a set pattern but a dynamic process. It mainly contains confirming organizational objectives, performance objectives, decomposition of performance objectives, decomposition of department and post and performance indicators and criterion of every department and post. At the same time, it monitors the work duly, seeks for the information which reflects the level of performance, measures the level of performance and apply evaluation results into practice.

At present, China mainly adopts several performance evaluation methods to manage performance evaluation. The comparison of the merits and demerits are shown in the table 1. 
Table 1. The comparison of several performance evaluation methods' merits and demerits.

\begin{tabular}{|c|c|c|}
\hline Method & Advantages & Defects \\
\hline Indicators Analysis & Statistics are more objective and easily obtained. & $\begin{array}{l}\text { The calculation is one-sides and not comprehensive } \\
\text { enough. }\end{array}$ \\
\hline The Balanced Scorecard & $\begin{array}{l}\text { It fully reflects enterprisestrategy. It combines } \\
\text { non-financial indicators with financial indicators and } \\
\text { combines short-term objectives with long-term } \\
\text { objectives. }\end{array}$ & $\begin{array}{l}\text { It pays less attention to the benefit of personnel, } \\
\text { stockholders and clients and mainly makes } \\
\text { quantitative analysis. It uses a bit of quantitative } \\
\text { indicators. }\end{array}$ \\
\hline Key Performance Indicator & $\begin{array}{l}\text { Indicators are closely relevant to enterprise strategy, } \\
\text { enterprises' strategy thoughts can be fully reflected. }\end{array}$ & $\begin{array}{l}\text { It has worse flexibility and it can't change according } \\
\text { to its enterprise strategy. There's no definite internal } \\
\text { connection between indicators. }\end{array}$ \\
\hline Economic Value Added & $\begin{array}{l}\text { Considering cost of equity, overcoming the short-term } \\
\text { behaivour benefits the establishment and long-term } \\
\text { development of incentive system. }\end{array}$ & \\
\hline
\end{tabular}

\subsection{The Basic Theory of Performance Evaluation}

\subsubsection{Principal-Agency Theory}

In classic enterprise, the right of ownership and management wasn't separated with each other. Thus, there's no need to specially establish the incentive mechanism in allusion to operators. Owners and operators are principal-agent relationship: enterprise owners are principal, CEOs are agent. The Principal-Agency Theory discusses that the principal can reach the purpose of controlling the agent by carrying out a contract with incentive meaning so that long-acting CEO salary incentive mechanism can be established by constantly studying the efficiency of the contract.

\subsubsection{Management Motivation Theory}

Motivation is one of the important functions in management. The motivation theory on behavior cannot count. There are mainly two kinds which CEO Motivation Mechanism relates: Content Motivation Theory and Process Motivation Theory.

Content Motivation Theory is based on the reason that raised behavior in order to seek for behavior motivation. The representative theory mainly contains Theory of Hierarchical Needs, Two Factor Theory, Achievement Motivation Theory and ERG Theory.

Process Motivation Theory focuses on the psychological process from motivation appearing to taking action in order to find the common process which explains incentive behavior. Comparing with Content Motivation Theory, this kind of theory mainly concentrates on the process instead of specific content. It can be applied widely for this reason. Process Motivation Theory has various kinds, mainly including Reinforcement Theory, Goal-Setting Theory, Expectancy Theory and Equity Theory.

\subsubsection{Contract Theory}

In Contract Theory, the principal (owner) must design suitable contract to constraint agents' behavior and inspire agents' positivity in order to restrict agents' limits of authority. Under the spirit of contract, the principal's best choice is signing a lease contract about the whole enterprise with the agent. The agent lessees the whole enterprise of the principal and pays scheduled rent. The agent owns all of the rest benefits of the enterprise. By using the way, the right of ownership and management are separated with each other and the arising problem can be solved completely by agents' self-inspiration and self-supervision.

\subsubsection{Evaluation Theory}

Evaluation is a process that people judge and evaluate the value of mankind and things by using objective criterion on the premise of a certain purpose. Evaluation should confirm the objective, and then attain information and form the value judgement. The three points are also the three procedures. People's acknowledgement and command to objective things come from the evaluation. Thus, people try their best to take scientific and positive measures to improve the level of productivity to attain more benefit. In addition, as the scope and content of evaluation theory become more complicated, people's acknowledgement to enterprises' operating management becomes constantly deep. The identical process of evaluation only can be accurate by integrating numbers of types, gradation and objects. Therefore, evaluation are moving towards the comprehensive evaluation period in which all types of evaluation integrate with each other.

\section{The Establishment of the Listed Companies' Operating Performance Evaluation System Model}

\subsection{The Choice of Evaluation Indicators}

\subsubsection{Indicators Reflecting Profitability}

Profitability is not only related to the benefit of enterprise owners, but also one of the important source of paying back debt. There are various indicators reflecting profitability. The paper chooses four representative indicators: ROEWA, Asset Profit Ratio, Income Margin and Ratio Of profits cost and expense.

ROEWA can be used to measure the level of earnings of stockholders' rights and interests. It can compensate for the lack of profit per share after levying a tax. This paper uses ROAE. It's a positive indicator which indicates the average of the level of the operators' capacity of creating new profit for the company when using net assents per share during the period of operating. The higher the indicator value is, the better the company is. 


$$
\begin{gathered}
\text { ROEWA }= \\
\mathrm{P} /\left(\mathrm{E}_{0}+\mathrm{NP} \div 2+\mathrm{E}_{\mathrm{i}} \times \mathrm{M}_{\mathrm{i}} \div \mathrm{M}_{0}-\mathrm{E}_{\mathrm{j}} \times \mathrm{M}_{\mathrm{j}} \div \mathrm{M}_{0} \pm \mathrm{E}_{\mathrm{k}} \times \mathrm{M}_{\mathrm{k}} \div \mathrm{M}_{0}\right) \times 100 \%
\end{gathered}
$$

Among the equation, $\mathrm{P}$; the net profit belonging to common stock holders after deducting recurrent profit and loss. NP: the net profit belonging to common stock holders. $\mathrm{E}_{0}$ : beginning net assets belonging to common stock holders. $E_{i}$ : the net assets which belong to common stock holders and are newly increased by issuing new shares and debt to equity in report period. $E_{j}$ : he net assets which belong to common stock holders and are reduced by repurchasing and cash bonuses in report period. $\mathrm{M}_{0}$ : the number of months of report period. $\mathrm{M}_{\mathrm{i}}$ : the number of months from the next month of adding new assets to the end of report period. $\mathrm{M}_{\mathrm{j}}$ : he number of months from the next month of reducing new assets to the end of report period. $\mathrm{E}_{\mathrm{k}}$ : the increase and decrease of net assets arising by other deals and matters. $\mathrm{M}_{\mathrm{k}}$ : the number of months from the next month of the net assets' increase and decrease to the end of report period.

Asset Profit Ratio is the comparison between gross average of profits and assets, which mainly measures the capacity of earning profits by using assets. It reflets utilization efficiency of enterprises' total assets. The higher the ratio is, the better the capacity of earning profits. Asset Profit Ratio (rate of return on total assets) is equal to the percentage of total profit and average total assets.

Income Margin=total operating profit/total operating income $\times 100 \%$. It reflects the relationship between sales revenue and profit. The indicator denotes the basic capacity of earning profit in business operation. The higher Income Margin is, the higher profit and product add-value are. In the market of main business, the greater competitiveness and development potential is, the higher the level of earning profit is.

Ratio of profits cost and expense $=$ total operating profit/total operating expense $\times 100 \%$. It reflects the relationship between the cost and profit. The higher indicator indicates that company has less cost of earning benefit. The better cost control is, the higher the level of earning profit is.

\subsubsection{The Indicator Reflecting the Growth of Operating}

The growth of operating reflects the trend of growth of operating in a period of time. It's the most important trend indicator for enterprises. To a company, if operating can't grow due to fixed input, the company may not develop and even can't compensate for fixed expense. The paper chooses three indicators, including profit increase rate, the preserving and appreciation of state-owned capital and ratio of ecnomic profit.

Profit increase rate $=($ total profit of this year-total profit of last year)/ total profit of last year $\times 100 \%$. It's the amplification of current period comparing with last period. The indicator can reflect the trend and degree of main business profits' growth which reflects company's constant capacity of development. It's the important indicator reflecting the potential growth of operating.

The preserving and appreciation of state-owned capital is equal to the ratio of (state-owned capital at the end of the year \pm objective factors increase or decrease the forehead) and state-owned capital at the beginning of the year. It reflects the situation of capital actual changes and the situation of capital preservation and appreciation cautiously and moderately. It indicates capital appreciates when the indicator is greater than 1. The greater the indicator is, the more capital accumulation is, the stronger business capital preservation is. It indicates capital devalues and doesn't preserve when the indicator is less than 1. It indicates capital preserves when the indicator is equal to 1 .

Ratio of economic profit $=$ (net profit - the average balance of net assets $\times$ cost of funds)/ the average balance of net assets $\times 100 \%$.

Cost of funds is weighted average cost of funds whose weight is percentage of time of one-year working capital loans' different rates published by People's Bank of China.

\subsubsection{The Indicator Reflecting Quality of Assets}

The paper chooses indicators including the ratio of net capital and risk and the ratio of net capital and net asset.

the ratio of net capital and risk=net capital at the end of the period/sum of risks $\times 100 \%$

Before conducting various business and allocating profits, People should conduct sensitivity analysis in allusion to risk control indicator, establish dynamic risk control indicator monitoring and complement mechanism and make sure that the reasonability and normalization of risk indicators including net assets.

\subsubsection{The Indicator Reflecting Capacity of Paying}

The capacity of paying is the key to enterprise healthy survival and development and the important symbol to reflect financial safety and operating capacity. The paper chooses debt to assets ratio and net capital debts ratio to reflect company's debt-paying ability.

Debt to assets ratio is the ratio of total liablities and total assets, which reflects the ratio of total assets by means of contracting a loan. Debt to assets ratio is regarded as financial leverage by scholars who study financial analysis. But it's a moderate indicator and there's no acknowledged standard. Generally speaking, most researches consider that $50 \%$ is the reasonable and moderate value.

Net capital debts ratio is the coverage ratio of net capital and liabilities at the end of period. Net assets debts ratio= net capital at the end of period/ liabilities at the end of period $\times 100 \%$. Among the equation, liabilities means exterior liabilities, except receivings from vicariously traded securities.

\subsection{The Establishment of Evaluation Model}

\subsubsection{The Choice of Evaluation Methods}

Factor analysis is a kind of multivariate statistics model method which extracts common factor from variates. It uses the thought of dimensionality reduction to devide original variates into groups based on correlation. It makes variates 
with higher correlation a group and makes variates with lower correlation differrent groups. The paper takes principal component analysis as the method of estimation of the factor loading matrix. In the operating evaluation of China's listed securities companies, Factor analysis aims to simplify several variates into minor main factors with more information to further analyse these minor main factors. So, we need to make factors into linear combination of several variates. $F=f(x)$ is called as the factor score function. It's also the China's listed securities companies' operating comprehensive evaluation function. It can be used to calculate each factor's situation of scores. In order to make it easier to explain, we need to rotate the factor loading matrix. In all kinds of rotation methods, Varimax is the most commonly used methods. Factor rotation makes the average value of factor loading in factor loading matrix divided in two directions of 0 and 1 . It makes big loading bigger, small loading smaller.

\subsubsection{The Choice and Economic Explanation of Main Factor}

Factor analysis is meant to seek for definitely meaningful common factor and resolves original variables to common parts and individual parts in frame of it to find out the contacts and distinctions between original variables. When main factor loading is hard to explain, loading matrix should be orthogonal transformed. That's to say, it can be a easy structure for factors explaining when factor information is allocated again. Its features are that it can copy information content of objects completely with no change and it can make what objects are clearer by some adjustion. The paper uses the average value of 2013 and 2014 when doing Factor analysis.

Table 2 shows the results of KMO and Bartlett. From the table, the value of KMO is 0.732 . According to the standard given by statistician, Kaiser, it's suitable to do Factor Analysis when the value of KMO is greater than 0.5 . The concomitant probability of Bartlett is 0.000 , which is less than the level of significance 0.05 . Therefore, refuse the null hypothesis of Bartlett and consider it suitable for Factor Analysis.

Table 2. KMO and Bartlett.

\begin{tabular}{llll}
\hline Sample enough & Bartlett & & \\
\cline { 2 - 4 } Kaiser-Meyer-Olkin & The approximate chi-square & df & Sig. \\
\hline .732 & 1021.591 & 55 & .000 \\
\hline
\end{tabular}

\subsubsection{The Establishment of Evaluation Model}

Recent years, the theory and methods of Factor Analysis are widely used by multiple areas like economics, medical science, psychology and so on. This enriches the method. Factor Analysis's common model is:

$$
\begin{aligned}
& \mathrm{X}_{1=} \mathrm{a}_{11} \mathrm{~F}_{1}+\mathrm{a}_{12} \mathrm{~F}_{1} \ldots+\mathrm{a}_{1} \mathrm{nF}_{1 \mathrm{n}}+\mathrm{e}_{1} \\
& \mathrm{X}_{2}=\mathrm{a}_{21} \mathrm{~F}_{1}+\mathrm{a}_{22} \mathrm{~F}_{2} \ldots+\mathrm{a}_{2} \mathrm{nf}_{2 \mathrm{n}}+\mathrm{e}_{2}
\end{aligned}
$$

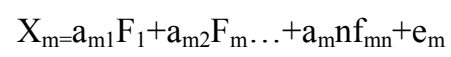

Among the model, $\mathrm{X}_{1}, \mathrm{X}_{2}, \mathrm{X}_{\mathrm{m}}$ are the variates which we need to actually measure. They are also the indicators of China's listed securities companies' operating evaluation. $a_{i j}(i$ $=1,2, \ldots, m ; j=1,2, \ldots, n)$ are factor loading, $F_{i}(i=1,2, \ldots$, $\mathrm{m})$ are common factors, $\mathrm{e}_{\mathrm{i}}(\mathrm{i}=1,2, \ldots, \mathrm{m})$ are special factors.

Factor loading a $\mathrm{ij}$ is the loading which the ith variate is in the jth main factor. It can also be considered as the correlation index. It indicates that the relationship between the ith variate and the jth factor becomes alienative when the loading becomes smaller and the correlation index becomes smaller. On the contrary, It indicates that the relationship between the ith variate and the jth factor becomes close when the loading becomes larger and the correlation index becomes larger.

\section{The Empirical Research of Listed Companies' Operating Performance Evaluation}

\subsection{The Dispose and Test of Sample Statistics}

The paper chooses statistic in 2013 and 2014 of 18 listed securities companies in Shenzhen and Shanghai as objects of study. The statistics of samples are from China securities regulatory commission website and Guotai junan database. China securities regulatory commission website is an official website hosteb by China securities regulatory commission. Thus, It can provide all linds of accurate, authoritative and convenient statistics information for vast researchers. The research database products and service of series of CSMAR is developed independently by Shenzhen Guotai Junan information technology limited company which are appreciated by academic circles. Thus, the statistics of the paper are accurate, authoritative and reliable. The paper uses SPSS11.5 and EXCEL to dispose statistics.

\begin{tabular}{|c|c|c|c|}
\hline Type & Name & Code & \multirow{8}{*}{$\begin{array}{l}\text { Computational formula } \\
\text { ROEWA }=\mathrm{P} /\left(\mathrm{E}_{0}+\mathrm{NP} \div 2+\mathrm{E}_{\mathrm{i}} \times \mathrm{M}_{\mathrm{i}} \div \mathrm{M}_{0}-\mathrm{E}_{\mathrm{j}} \times \mathrm{M}_{\mathrm{j}} \div \mathrm{M}_{0} \pm \mathrm{E}_{\mathrm{k}} \times \mathrm{M}_{\mathrm{k}} \div \mathrm{M}_{0}\right) \times 100 \% \\
\text { total profit/average total assets } \times 100 \% \\
\text { Income Margin=total operating profit/total operating income } \times 100 \% \\
\text { Ratio Of profits cost and expense }=\text { total operating profit/total operating } \\
\text { expense } \times 100 \% \\
\text { (state-owned capital at the end of the year } \pm \text { objective factors increase or decrease } \\
\text { the forehead)/state-owned capital at the beginning of the year } \times 100 \% \\
\text { (total profit of this year-total profit of last year)/ total profit of last year } \times 100 \% \\
\text { (net profit }- \text { the average balance of net assets } \times \text { cost of funds)/ the average balance } \\
\text { of net assets } \times 100 \%\end{array}$} \\
\hline \multirow{4}{*}{$\begin{array}{l}\text { The capacity of } \\
\text { earing profit }\end{array}$} & ROEWA & $\mathrm{X}_{1}$ & \\
\hline & Asset Profit Ratio & $\mathrm{X}_{2}$ & \\
\hline & Income Margin & $\mathrm{X}_{3}$ & \\
\hline & Ratio of profits cost and expense & $\mathrm{X}_{4}$ & \\
\hline \multirow{3}{*}{$\begin{array}{l}\text { The growth of } \\
\text { operating }\end{array}$} & $\begin{array}{l}\text { the preserving and appreciation of } \\
\text { state-owned capital }\end{array}$ & $\mathrm{X}_{5}$ & \\
\hline & profit increase rate & $\mathrm{X}_{6}$ & \\
\hline & ratio of economic profit & $\mathrm{X}_{7}$ & \\
\hline
\end{tabular}

Table 3. summary table of primary indicators. 


\begin{tabular}{llll}
\hline Type & Name & Code & Computational formula \\
\hline \multirow{2}{*}{ The quality of assets } & the ratio of net capital and risk & $\mathrm{X}_{8}$ & net capital at the end of the period/sum of risks $\times 100 \%$. \\
The capacity of & the ratio of net capital and net asset & $\mathrm{X}_{9}$ & net capital at the end of the period/net asset at the end of the period $\times 100 \%$ \\
paying & net capital debts ratio & $\mathrm{X}_{10}$ & net capital at the end of period/ liabilities at the end of period $\times 100 \%$ \\
debt to assets ratio & $\mathrm{X}_{11}$ & total liabilities at the end of the period /total assets at the end of the period \\
\hline
\end{tabular}

\subsection{Extract Public Factors}

Table 4. Eigenvalues and variance contribution rate of factors.

\begin{tabular}{|c|c|c|c|c|c|c|c|c|c|}
\hline \multirow[b]{2}{*}{ element } & \multicolumn{3}{|c|}{ initial eigenvalues } & \multicolumn{3}{|c|}{ extraction of sum of squares loaded } & \multicolumn{3}{|c|}{ rotate the sum of squares loaded } \\
\hline & summation & $\begin{array}{l}\text { variance } \\
\%\end{array}$ & $\begin{array}{l}\text { accumulative } \\
\text { total } \%\end{array}$ & summation & $\begin{array}{l}\text { variance } \\
\%\end{array}$ & $\begin{array}{l}\text { accumulative } \\
\text { total } \%\end{array}$ & summation & variance $\%$ & $\begin{array}{l}\text { accumulative } \\
\text { total } \%\end{array}$ \\
\hline 1 & 5.558 & 50.527 & 50.527 & 5.558 & 50.527 & 50.527 & 4.921 & 44.733 & 44.733 \\
\hline 2 & 2.204 & 20.036 & 70.563 & 2.204 & 20.036 & 70.563 & 2.074 & 18.857 & 63.590 \\
\hline 3 & 1.096 & 9.968 & 80.531 & 1.096 & 9.968 & 80.531 & 1.218 & 11.073 & 74.663 \\
\hline 4 & .940 & 8.544 & 89.075 & .940 & 8.544 & 89.075 & 1.103 & 10.028 & 84.691 \\
\hline 5 & .611 & 5.551 & 94.625 & .611 & 5.551 & 94.625 & 1.093 & 9.934 & 94.625 \\
\hline 6 & .265 & 2.409 & 97.034 & & & & & & \\
\hline 7 & .134 & 1.218 & 98.252 & & & & & & \\
\hline 8 & .106 & .960 & 99.212 & & & & & & \\
\hline 9 & .050 & .454 & 99.666 & & & & & & \\
\hline 10 & .035 & .320 & 99.986 & & & & & & \\
\hline 11 & .002 & .014 & 100.000 & & & & & & \\
\hline
\end{tabular}

The contribution rate of public factors shows the quantity of original indicators' information reflecting by public factors. The cumulative contribution rate shows the quantity of original indicators' information reflecting by relevant public factors. From the table 5, the first five factors' cumulative contribution rate is up to $94.625 \%$. That's to say, the first five factors can reflect $94.625 \%$ quantity of original indicators' information. Thus, extract five public factors including F1, F2, F3, F4, F5

Table 5. Initial factors loading matrix.

\begin{tabular}{llllll}
\hline \multirow{2}{*}{ Indicator } & element & \multicolumn{1}{l}{} \\
\cline { 2 - 6 } & $\mathbf{1}$ & $\mathbf{2}$ & $\mathbf{3}$ & $\mathbf{4}$ & $\mathbf{5}$ \\
\hline $\mathrm{X}_{1}$ & .950 & .033 & .015 & .172 & .113 \\
$\mathrm{X}_{2}$ & .939 & .066 & .022 & .180 & .050 \\
$\mathrm{X}_{3}$ & .801 & .245 & -.057 & -.438 & .072 \\
$\mathrm{X}_{4}$ & .834 & .267 & -.003 & -.362 & .149 \\
$\mathrm{X}_{5}$ & .907 & .030 & .154 & .219 & -.066 \\
$\mathrm{X}_{6}$ & .682 & .141 & .131 & .117 & -.679 \\
$\mathrm{X}_{7}$ & .947 & .019 & -.006 & .096 & .232 \\
$\mathrm{X}_{8}$ & -.266 & .624 & .400 & -.533 & -.111 \\
$\mathrm{X}_{9}$ & -.177 & -.060 & .930 & .210 & .172 \\
$\mathrm{X}_{10}$ & -.274 & .915 & -.083 & .271 & .065 \\
$\mathrm{X}_{11}$ & -.274 & .903 & -.142 & .287 & .054 \\
\hline
\end{tabular}

From the table above, the meaning of public factors is dim and it can't explain factors perfectly. Thus, it's necessary for factor loading matrix to rotate. the factor loading matrix is as follows in table 6 after conducting factor rotation by Varimax.
Table 6. Factor loading matrix after rotating.

\begin{tabular}{llllll}
\hline \multirow{2}{*}{ Indicator } & element & \multicolumn{3}{l}{} \\
\cline { 2 - 6 } & $\mathbf{1}$ & $\mathbf{2}$ & $\mathbf{3}$ & $\mathbf{4}$ & $\mathbf{5}$ \\
\hline $\mathrm{X}_{1}$ & .919 & -.067 & -.218 & .002 & .225 \\
$\mathrm{X}_{2}$ & .894 & -.040 & -.198 & -.003 & .284 \\
$\mathrm{X}_{3}$ & .822 & -.096 & .367 & -.273 & .086 \\
$\mathrm{X}_{4}$ & .882 & -.053 & .319 & -.187 & .053 \\
$\mathrm{X}_{5}$ & .826 & -.077 & -.182 & .113 & .407 \\
$\mathrm{X}_{6}$ & .444 & -.032 & .044 & -.049 & .880 \\
$\mathrm{X}_{7}$ & .952 & -.097 & -.185 & -.018 & .095 \\
$\mathrm{X}_{8}$ & -.130 & .317 & .880 & .157 & .010 \\
$\mathrm{X}_{9}$ & -.082 & -.043 & .114 & .975 & -.025 \\
$\mathrm{X}_{10}$ & -.078 & .982 & .156 & .002 & -.025 \\
$\mathrm{X}_{11}$ & -.087 & .986 & .119 & -.048 & -.021 \\
\hline
\end{tabular}

Table 5 is the result of Varimax using factor loading matrix in table 6 . It can be seen that the first main factors are mainly decided by variates $\mathrm{X}_{1}, \mathrm{X}_{2}, \mathrm{X}_{3}, \mathrm{X}_{4}, \mathrm{X}_{5}, \mathrm{X}_{7}$. The loadings in their main factors are $0.919,0.894,0.822,0.882,0.826$ and 0.952 . The second main factors are mainly decided by variates $\mathrm{X}_{10}, \mathrm{X}_{11}$. The loadings in their main factors are 0.982 and 0.986 . The third main factors are mainly decided by variates $\mathrm{X}_{3}$. The loading in their main factor is 0.880 . The fourth main factors are mainly decided by variates $\mathrm{X}_{9}$. The loading in their main factor is 0.975 . The fifth main factors are mainly decided by variates $\mathrm{X}_{6}$. The loading in their main factor is 0.880 .

The economic explanations of public factors are as follows:

Table 7. The name of main factors.

\begin{tabular}{|c|c|c|c|c|c|}
\hline Variate & Factor 1(F1) & Factor2(F2) & Factor3(F3) & Factor4(F4) & Factor5(F5) \\
\hline $\begin{array}{l}\text { The representative } \\
\text { indicator of main } \\
\text { factors }\end{array}$ & $\begin{array}{l}\text { ROEWA, Asset Profit Ratio, } \\
\text { Income Margin, Ratio Of profits } \\
\text { cost and expense, the preserving and } \\
\text { appreciation of state-owned capital, } \\
\text { profit increase rate }\end{array}$ & $\begin{array}{l}\text { net capital debts } \\
\text { ratio, debt to assets } \\
\text { ratio }\end{array}$ & $\begin{array}{l}\text { the ratio of net } \\
\text { capital and risk }\end{array}$ & $\begin{array}{l}\text { the ratio of net } \\
\text { capital and net asset }\end{array}$ & profit increase rate \\
\hline
\end{tabular}




\subsection{Evaluation Result Analysis}

In order to comprehensively evaluate China's listed securities companies' evaluation system, calculate the score of five public factors and achieve the score coefficient matrix. Table4-6 is the score coefficient matrix of each factor:

Table 8. Factor score coefficient matrix.

\begin{tabular}{llllll}
\hline \multirow{2}{*}{ Indicator } & element & \multicolumn{3}{l}{} \\
\cline { 2 - 6 } & $\mathbf{1}$ & $\mathbf{2}$ & $\mathbf{3}$ & $\mathbf{4}$ & $\mathbf{5}$ \\
\hline $\mathrm{X}_{1}$ & .215 & .071 & -.179 & .093 & -.074 \\
$\mathrm{X}_{2}$ & .183 & .078 & -.163 & .081 & .024 \\
\hline
\end{tabular}

\begin{tabular}{llllll}
\hline \multirow{2}{*}{ Indicator } & element & \multicolumn{3}{l}{} \\
\cline { 2 - 6 } & $\mathbf{1}$ & $\mathbf{2}$ & $\mathbf{3}$ & $\mathbf{4}$ & $\mathbf{5}$ \\
\hline $\mathrm{X}_{3}$ & .204 & -.101 & .384 & -.199 & -.168 \\
$\mathrm{X}_{4}$ & .252 & -.056 & .321 & -.103 & -.256 \\
$\mathrm{X}_{5}$ & .119 & .049 & -.136 & .168 & .222 \\
$\mathrm{X}_{6}$ & -.229 & -.031 & .108 & -.087 & 1.101 \\
$\mathrm{X}_{7}$ & .278 & .052 & -.148 & .088 & -.272 \\
$\mathrm{X}_{8}$ & -.014 & -.038 & .741 & .098 & .102 \\
$\mathrm{X}_{9}$ & .090 & -.015 & .061 & .911 & -.088 \\
$\mathrm{X}_{10}$ & .052 & .511 & -.095 & .029 & -.028 \\
$\mathrm{X}_{11}$ & .042 & .519 & -.127 & -.017 & -.016 \\
\hline
\end{tabular}

$\mathrm{F} 1=0.215 * \mathrm{X}_{1}+0.183 * \mathrm{X}_{2}+0.204 * \mathrm{X}_{3}+0.252 * \mathrm{X}_{4}+0.119 * \mathrm{X}_{5}-0.229 * \mathrm{X}_{6}+0.278 * \mathrm{X}_{7}-0.014 * \mathrm{X}_{8}+0.090 * \mathrm{X}_{9}+0.052 * \mathrm{X}_{10}+0.042 * \mathrm{X}_{11}$

The calculations of F2, F3, F4, F5 are done in the same manner.

Due to every main factor only reflects the capacity of samples in some ways, the operating performance evaluation model can be acquired by using contribution rate of the main factor eigenvalue as weight:

$\mathrm{EQI}=(29.711 * \mathrm{~F} 1+29.201 * \mathrm{~F} 2+22.841 * \mathrm{~F} 3+31.256 * \mathrm{~F} 4+26.345 * \mathrm{~F} 5) / 81.752$

$=0.3634 * \mathrm{~F} 1+0.3572 * \mathrm{~F} 2+0.2794 * \mathrm{~F} 3+0.3823 * \mathrm{~F} 4+0.3222 * \mathrm{~F} 3$

Among the equation, F1, F2, F3, F4, F5 are the five public factors extracted.

$\mathrm{F} 1=0.215 * \mathrm{X}_{1}+0.183 * \mathrm{X}_{2}+0.204 * \mathrm{X}_{3}+0.252 * \mathrm{X}_{4}+0.119 * \mathrm{X}_{5}-0.229 * \mathrm{X}_{6}+0.278 * \mathrm{X}_{7}-0.014 * \mathrm{X}_{8}+0.090 * \mathrm{X}_{9}+0.052 * \mathrm{X}_{10}+0.042 * \mathrm{X}_{11}$

\section{The Efficiency of Model}

\subsection{The Comprehensive Score of Each Factor}

Table 9. Factor score and comprehensive score in 2013 of sample company.

\begin{tabular}{|c|c|c|c|c|c|c|c|}
\hline Stock code & The name of enterprise & F1 & F2 & F3 & F4 & F5 & EQI \\
\hline 000562 & Hong Yuan Securities Co., Ltd & 0.37117 & -0.43227 & -0.41869 & -0.72464 & -0.13217 & -0.05 \\
\hline 000686 & Northest Securities Co., Ltd & 0.24784 & -0.42945 & -0.94082 & 2.31209 & -0.64370 & 0.09 \\
\hline 000728 & GuoYuan Securities Co., Ltd & -0.21097 & 0.92291 & 2.57861 & 0.13531 & 0.03995 & 0.38 \\
\hline 000776 & GF Securities Co. Ltd & 0.71756 & -0.32590 & -0.92077 & -1.29347 & -0.41763 & -0.01 \\
\hline 000783 & Changjiang Securities Co., Ltd & 0.10085 & -0.48505 & -0.03175 & -0.01202 & -0.23509 & -0.07 \\
\hline 002500 & Shanxi Securities Co., Ltd & -0.12868 & 1.99055 & 0.03856 & 0.25725 & -0.05769 & 0.34 \\
\hline 600030 & CITIC Securities Co., Ltd & 0.46923 & -0.46094 & 0.49314 & -1.06427 & -0.01525 & 0.07 \\
\hline 600109 & Guojin Securities Co., Ltd & 0.05068 & -0.03658 & -0.14246 & 1.79816 & 0.02152 & 0.18 \\
\hline 600369 & Southwest Securities Co., Ltd & 0.14345 & 0.24686 & 1.04680 & 0.35022 & -0.32869 & 0.23 \\
\hline 600837 & Haitong Securities Co., Ltd & -0.25833 & 0.25958 & 0.55503 & -0.48930 & -0.16553 & -0.07 \\
\hline 600999 & China Merchants Securities Co., Ltd & 0.24997 & -0.62581 & -0.05742 & -1.99146 & -0.57767 & -0.27 \\
\hline 601099 & The Pacific Securities Co., Ltd & -0.30977 & -0.48649 & -0.03070 & 1.41369 & -0.24234 & -0.12 \\
\hline 601377 & Industrial Securities Co., Ltd & -0.06867 & -0.31022 & -0.07530 & 0.41252 & -0.17397 & -0.07 \\
\hline 601555 & Soochow Securities Co., Ltd & -0.05266 & -0.23294 & -0.83056 & -0.40640 & -0.22500 & -0.22 \\
\hline 601788 & Everbright Securities Co., Ltd & 0.15699 & 0.34101 & 0.68429 & -0.09312 & -0.51009 & 0.15 \\
\hline 601901 & Founder Securities Co., Ltd & 0.37945 & 0.00834 & 0.08914 & -0.37590 & -0.29805 & 0.11 \\
\hline
\end{tabular}

Table 10. Factor score and comprehensive score in 2014 of sample company.

\begin{tabular}{|c|c|c|c|c|c|c|c|}
\hline Stock code & The name of enterprise & F1 & F2 & F3 & F4 & F5 & EQI \\
\hline 000562 & Hong Yuan Securities Co., Ltd & -0.65092 & -0.50775 & -0.61817 & -1.11184 & -0.30008 & -0.60 \\
\hline 000686 & Northest Securities Co., Ltd & -2.21218 & -0.39087 & -1.56874 & 2.11986 & -0.11620 & -1.04 \\
\hline 000728 & GuoYuan Securities Co., Ltd & -0.70032 & 1.85340 & 1.43807 & -0.54478 & 0.06759 & 0.15 \\
\hline 000750 & Sealand Securities Co., Ltd & -1.35221 & -0.44411 & -1.55471 & 0.32866 & -0.08692 & -0.84 \\
\hline 000776 & GF Securities Co. Ltd & -0.47325 & -0.49284 & 0.04335 & -0.50627 & -0.36060 & -0.39 \\
\hline 000783 & Changjiang Securities Co., Ltd & -1.12023 & -0.48583 & -0.27077 & -0.08815 & -0.09808 & -0.64 \\
\hline 002500 & Shanxi Securities Co., Ltd & -0.59734 & 6.69653 & -1.38764 & -0.35444 & -0.13676 & 0.79 \\
\hline 002673 & Western Securities Co., Ltd & -0.63056 & 0.69510 & -0.77088 & 0.70956 & -0.34899 & -0.20 \\
\hline
\end{tabular}




\begin{tabular}{|c|c|c|c|c|c|c|c|}
\hline Stock code & The name of enterprise & F1 & F2 & F3 & F4 & F5 & EQI \\
\hline 600030 & CITIC Securities Co., Ltd & 0.45507 & -0.56323 & 0.98187 & -1.03328 & -0.42178 & 0.06 \\
\hline 600109 & Guojin Securities Co., Ltd & -0.69706 & -0.35569 & 0.04291 & 1.19040 & -0.04469 & -0.26 \\
\hline 600369 & Southwest Securities Co., Ltd & -1.30624 & -0.44924 & 0.56111 & 0.24514 & 0.06678 & -0.58 \\
\hline 600837 & Haitong Securities Co., Ltd & -0.61390 & -0.53120 & 0.45979 & -0.86689 & 0.04178 & -0.41 \\
\hline 600999 & China Merchants Securities Co., Ltd & -0.47411 & -0.64184 & 0.32398 & -1.83894 & -0.20473 & -0.50 \\
\hline 601099 & The Pacific Securities Co., Ltd & -0.71271 & -0.51756 & -0.31542 & 1.30787 & 0.13346 & -0.31 \\
\hline 601377 & Industrial Securities Co., Ltd & -0.99192 & -0.51964 & -0.31748 & -0.47398 & 0.09318 & -0.62 \\
\hline 601555 & Soochow Securities Co., Ltd & -1.03113 & -0.18461 & 0.18640 & 0.54235 & 0.05858 & -0.42 \\
\hline 601688 & Huatai Securities Co., Ltd & -0.50364 & 0.68366 & -0.32344 & -1.12872 & -0.24240 & -0.27 \\
\hline 601788 & Everbright Securities Co., Ltd & -1.38871 & 0.64606 & 0.06031 & -1.35565 & 0.05658 & -0.62 \\
\hline 601901 & Founder Securities Co., Ltd & -0.65092 & -0.50775 & -0.61817 & -1.11184 & -0.30008 & -0.60 \\
\hline
\end{tabular}

\subsection{Factor Score and Rank of Each Company}

Table 11. The sample company league table.

\begin{tabular}{|c|c|c|c|c|c|c|c|c|c|}
\hline Stock code & The name of enterprise & Year 2013 & Year 2014 & Average & F1 & F2 & F3 & F4 & F5 \\
\hline 000562 & Hong Yuan Securities Co., Ltd & 8 & 13 & 18 & 8 & 13 & 15 & 17 & 18 \\
\hline 000686 & Northest Securities Co., Ltd & 18 & 18 & 2 & 19 & 8 & 19 & 1 & 14 \\
\hline 000728 & GuoYuan Securities Co., Ltd & 10 & 2 & 17 & 9 & 2 & 1 & 12 & 2 \\
\hline 000750 & Sealand Securities Co., Ltd & 16 & 17 & 8 & 17 & 9 & 18 & 8 & 8 \\
\hline 000776 & GF Securities Co. Ltd & 3 & 8 & 16 & 3 & 11 & 8 & 11 & 17 \\
\hline 000783 & Changjiang Securities Co., Ltd & 14 & 16 & 1 & 15 & 10 & 10 & 7 & 9 \\
\hline 002500 & Shanxi Securities Co., Ltd & 5 & 1 & 4 & 5 & 1 & 17 & 10 & 15 \\
\hline 002673 & Western Securities Co., Ltd & 7 & 4 & 3 & 12 & 5 & 16 & 5 & 16 \\
\hline 600030 & CITIC Securities Co., Ltd & 1 & 3 & 5 & 1 & 17 & 2 & 14 & 19 \\
\hline 600109 & Guojin Securities Co., Ltd & 9 & 5 & 12 & 11 & 7 & 9 & 3 & 10 \\
\hline 600369 & Southwest Securities Co., Ltd & 15 & 12 & 9 & 16 & 12 & 3 & 6 & 3 \\
\hline 600837 & Haitong Securities Co., Ltd & 6 & 9 & 11 & 6 & 16 & 4 & 13 & 4 \\
\hline 600999 & China Merchants Securities Co., Ltd & 2 & 11 & 7 & 2 & 19 & 5 & 19 & 11 \\
\hline 601099 & The Pacific Securities Co., Ltd & 11 & 7 & 14 & 10 & 14 & 11 & 2 & 1 \\
\hline 601377 & Industrial Securities Co., Ltd & 12 & 14 & 10 & 13 & 15 & 12 & 9 & 5 \\
\hline 601555 & Soochow Securities Co., Ltd & 13 & 10 & 6 & 14 & 6 & 6 & 4 & 6 \\
\hline 601688 & Huatai Securities Co., Ltd & 4 & 6 & 15 & 4 & 3 & 13 & 16 & 12 \\
\hline 601788 & Everbright Securities Co., Ltd & 17 & 15 & 6 & 18 & 4 & 7 & 18 & 7 \\
\hline 601901 & Founder Securities Co., Ltd & 8 & 13 & 15 & 7 & 18 & 14 & 15 & 13 \\
\hline
\end{tabular}

From table 11, for some listed securities companies, there's great difference between the situation of sorting by factors and average EQI before and after conduction. For example, CITIC Securities Co., Ltd ranks in NO.1 and NO.3 in 2013 and 2014 when sorting by average EQI. The company ranks in NO.17 and NO.19 when sorting by net capital debts ratio, debt to assets ratio and profit increase rate. There's great difference. That's to say, it tends to have limitation in evaluating listing securities companies' performance by using single indicator. No matter which indicator, it can't reflect the operating condition completely for its one-sidedness and objectivity. Many factors affect listed companies' performance. Thus, it's necessary to establish a comprehensive evaluation model to make comprehensive and objective evaluation. The evaluation model of this paper is a discussion of listed companies' comprehensive evaluation.

From table 11, the ranking of EQI of some listed securities companies changes obviously in 2013 and 2014 before and after conduction. For example, Guo Yuan Securities Co., Ltd (000728) ranks in NO.10 and NO.2 in 2013 and 2014. The score of each factor in two years is $F 1=-0.21097, F 2=0.92291$, $\mathrm{F} 3=2.57861, \mathrm{~F} 4=0.13531, \mathrm{~F} 5=0.03995,(2013) . \mathrm{F} 1=-0.70032$, $\mathrm{F} 2=1.85340, \mathrm{~F} 3=1.43807, \mathrm{~F} 4=-0.54478, \mathrm{~F} 5=0.06759$, (2014). That's to say, comparing with 2013, F2 and F3 rise sharply in 2014 which leads to the rise of ranking in 2014. This indicates the rise of net capital debts ratio, debt to assets ratio and the ratio of net capital and risk affects a lot in indicator ranking.

According to the factor ranking situation of the empirical analysis results, Northwest Securities Co., Ltd, Everbright Securities Co., Ltd and Guo Yuan Securities Co., Ltd ranks in NO.19, NO.18 and NO.17. Original indicators show, income Margin and Ratio Of profits cost and expense the three listed securities companies are the main elements which leads to the low level of profitability. So, they may enhance operating performance by enhancing income and reducing cost. They should enlarge the range of operating, save resource costs and enhance the operating efficiency. Nowadays, the income of China's listed securities companies comes from handling charge and commission, securities underwriting business, fund management fees and so on. Cost mainly includes operation and administrative expense. So, handling charge and fund management fees are the main source of profit. They should enlarge the range of operation and enrich the source of income. They should use America experience for reference in combination with China's reality to mix business moderately. For example, they can take part in the exploitation of some financial products in use of the advantage of so many branches. However, original listed securities companies should strengthen the precaution of operating risks and reduce the possibility of financial risks efficiently at the same time. Only 
in this way can they enhance the level of operating performance efficiently in the basis of assuring operating safety. China's listed securities companies should take absorbing excellent talents who are familiar with China's financial market and culture commercial banks as the important way of enhancing operating efficiency. They also need strengthen business training and staff with development potential learn new ideas and technology as soon as possible by training in order to enhance working efficiency. They also should absorb a plenty of talents with high quality, high level and high ability. These talents can give play to their peculiar advantages in business expansion and product development and enhance the research and development ability and market expansion ability of listed securities companies as a result. As a result, listed securities companies should improve motivation and restriction mechanism, reduce the loss of talents as much as possible and save resource costs as a result in order to enhance the profitability of China's listed securities companies.

According to the factor ranking situation of he empirical analysis results, CITIC Securities Co., Ltd, Hong Yuan Securities Co., Ltd and GF Securities Co., Ltd rank in NO.19, NO.18 and NO.17 in growth ranking. Original indicators show that the profit growth rate of the three listed securities companies is unsatisfied. Securities companies belong to the securities investment industry. The source of assets is clients' acting sale of securities. Companies' profit from the investment is commonly lower than banks' loan profit. Companies allocate less profit to clients leading to clients' low investment income which affects companies' brand benefit and clients' benefit. Thus, the key to enhance listed securities companies' operating performance is financial innovation. Financial innovation includes not only tradition operation tools but also financial derivatives. Financial innovation should include not only service innovation but also product innovation, information and technology innovation and management innovation. From development trend, China's listed securities companies' business and product innovation should mainly include asset business innovation, debt business innovation and intermediary business innovation.

\section{Conclusion}

By the research of the paper, in combination of the basic situation of listed securities companies, conclusion can be drawn: (1) Increasing international competition needs scientific and reasonable financial enterprises' operating performance evaluation. China should establish operating performance evaluation system which suits the financial enterprise development. Recent years, with China's combination of international market, foreign capital enters market. The mature operation mechanism and increasingly improved evaluation system threat China's financial enterprises in some way. Thus, the establishment of financial securities industry's operating performance system is extremely urgent. (2) Performance evaluation should form a whole system. Performance evaluation system normally includes the process of choice of evaluation objectives, the confirming of evaluation target, the choice of evaluation criterion, information collection and conclusion. None of them can be wiped out. (3) Compare listed securities companies' performance evaluation before and after conduction. It can be concluded that there's a little change in EQI ranking in 2013 and 2014 after the new performance regulation's conduction. Except several securities companies change in rank because of the change of operating performance, other else are basically in the same level. Different indicators may lead to the ranking change. It can be seen that debt to assets ratio and the ratio of net capital and profit increase rate affects the ranking change a lot from the analysis. This indicates new indicator system prominent the importance of safety and growth more often.

\section{Acknowledgements}

Supported by National Natural Science Foundation of China (71101076);

Supported by the MOE Layout Foundation of Humanities and Social Sciences (10YJA630147);

Supported by Natural Science Foundation of Nantong University (10ZY002).

\section{References}

[1] Wruck K. H. Equity Ownership Concentration and Firm Value: Evidence from Private Equity Financings [J]. Journal of Financial Economics, 1989 (25).

[2] Dodd P. Merger proposals management discretion and stockholder wealth [J]. Journal of Financial Economics, 1980, 8 (2).

[3] Chen S., HoK. W., Lee C., Yeo G. Wealth Effects of Private equity Placements evidence from Singapore $[\mathrm{J}]$. The Financial Review, 2002 (37).

[4] Healy P. M., Palepu K. G. and Ruback R. S. Do mergers improve corporate performance? [J]. Journal of Financial Economics, 1992, 31 (2).

[5] Hertzel Michael G., James S. L and Wintoki M. B. Institutional Investors and the Long-run Performance of Private Placement [J]. Journal of Finance, 2006 (48).

[6] Philippe Hertenstein. Finaneial Risk Manage Handbook, Johnwiley \& sons, Ine, 2000.

[7] Farrell M J. The measurement of productive efficiency. Journal of the Royal Statistical Society, 1957.

[8] Altman E. Corporate FinanCial Distress. New York University Warking PaPer, 1983.

[9] West. West R. C. A Faetor-analysis Approach to Bank Condition, Journal of Banking Finance, 1985, (9).

[10] Arshadi, E. C. Lawrenee. An Empirieal Investigation of New Bank Perform-ance, Journal of Banking and Finance, 1987.

[11] Joseph F Sinkey, Commercial bank Financial management [M], 2002. 
[12] Robert S. Kaplan, David P. Norton. The Strategy - Focused Organization: How Balanced Scorecard Companies Thrive in the New Business Envir-onment [M]. Harvard Business School Press, 1996.
[13] James M. Conway. Analysis and design of mutifactor -performance Appraisal studies. Journal of management, 1996, 1 (22): $139-152$. 